\title{
Developing Reading Learning Model to Increase Reading Skill for Animal Husbandry Students in Higher Education
}

\author{
Abd. Syakur ${ }^{1}$, Rosidi Azis ${ }^{2}$, Sukarsih ${ }^{3}$ \\ ${ }^{1}$ Postgraduate Program of English Education, STKIP PGRI Sidoarjo, Indonesia \\ 2Departments of Animal Husbandry, Universitas Nahdlatul Ulama Blitar, Indonesia \\ ${ }^{3}$ Departments of English Education, Universitas Islam Kadiri, Indonesia \\ Email: syakurabdmpd@gmail.com
}

\begin{abstract}
The development of teaching and learning activities must be evaluated to find out the success or failure of learning. This evaluation must be done because teaching now will certainly affect the next learning process, especially the reading comprehension model. This study aims to produce a reading comprehension model that is able to improve the reading comprehension skills of second semester students in the English for Professions subject to 2 Semester Credit Systems (SKS) in the department of animal husbandry at the University of Nahdlatul Ulama Blitar. The study approach used was Research and Development by modifying the ten steps of implementing the research strategy into three steps. The research subjects were lecturers and students majoring in animal husbandry at the University of Nahdlatul Ulama Blitar. Data collection techniques used was observation, questionnaires, interviews and tests. Research data analyzed using qualitative and quantitative analysis techniques. Data results show that the use of reciprocal teaching reading strategies combined with peer-teaching methods can significantly improve students' reading comprehension skills. The care giving effect arising from the application of reciprocal teaching to reading comprehension increases social values in second semester students in the English for Professional course.
\end{abstract}

Keywords: reading learning model; the understanding of reading material; reciprocal teaching

\section{Introduction}

In the current 4.0 industrial revolution era, work and business competition is more intense than before (Jöns and Hoyler, 2013, Hermann et al., 2016). Indonesia as a developing country that cannot be separated from the influence of this, which must have the readiness of human resources that are not only reliable but must also be competitive (Agussani and Ansari, 2020). Globalization has a wide impact on various fields of life, ranging from economics, politics, culture, to education (Ma et al., 2015, Azis and Kurniawan, 2019). Globalization triggers a knowledge-driven economy, which requires professional and highly skilled workers to work in the industrial, business and service sectors. Implications for the selection of reliable human resources in the era of the industrial revolution with the quality of service and mastery of international languages, namely English (Sulam et al., 2019). One of the requirements in the world of work is being able to communicate orally and in writing in English, because so much information in English that shows that English is an important thing that must be mastered (Robles, 2012).

The core learning of English in Indonesia includes 4 skills namely; writing, listening, reading, and speaking (Ningsih et al., 2014). These four skills are interrelated with one another and cannot be separated. Teaching reading English or reading are important things that are taught in majors or study programs outside of English as well as in animal husbandry study programs, the provision of teaching resources for non-English students is an absolute prerequisite for successful English learning. Required textbooks must include the design of the material, the suitability of the material and how it is presented. According to Widiastuti (2019) 
teaching materials should be designed and written according to the rules of learning, i.e. adapted to learning materials, arranged based on learning needs, there are evaluation materials, and the instructional materials are interesting for students to learn. This is the background of researchers in expressing the problems that arise in this study.

One of the reasons for teaching English in the department of animal husbandry of the University of Nahdlatul Ulama Blitar is to pursue world developments in the field of science and technology. Considering that most scientific works in the field of science and technology are released in English. Thus, the main objective of teaching reading in general is to develop reading skills, with the medium of general lecture handbooks in English.

According to observations, lectures in English as a General Basic Course (MKDU) in animal husbandry department at the University of Nahdlatul Ulama Blitar have been carried out using the English For Profession Module (ESP / English For Animal Husbandry), in which lecture material has been contained in the textbooks owned by every student. The availability of textbooks does have a positive impact, such as smooth lectures, programmed lecturer and student activities, and the patterning of student learning activities. However, this does not mean that the English for Profession (ESP) / English for Animal Husbandry Module is used free from deficiencies, especially when linked with the main aim of teaching English outside the English program, which is to develop reading skills in English. Almost all English For Profession (ESP) / English For Animal Husbandry Modules state that the main purpose of English language learning is to develop English reading skills. However, the material contained therein is more oriented to mastering the structure (grammar), while the text or reading text is placed at the end or as a complement. Most existing books only contain structure items, such as tenses, clauses, passive / active voice, and so on, and each section is also equipped with a series of structure training materials that are related to the material (Ningsih et al., 2014). Very few English For Profession (ESP) / English For Animal Husbandry Modules that contain English reading topics that are in accordance with the knowledge they learn because if given a rather difficult reading, they also seem unfamiliar with the vocabulary in them (Robles, 2012). Therefore, it can be concluded that the teaching of English in the University of Nahdlatul Ulama Blitar majoring in animal husbandry in particular is still oriented to mastering the structure of the English language, and not to the development of reading skills (Robles, 2012, Hariyati and Syakur, 2018).

Presentation of reading manuscripts is also inseparable from any shortcomings. First, the manuscripts are almost always read aloud by the lecturer with the intention of setting an example, as well as by some students who are asked to read aloud. Conducted in the library or in the study room. Second, although the text has been equipped with a list of difficult words, lecturers still often serve student questions about the meaning of words and structures that are not yet understood or no longer understood. The result is that the learning to read turns into refreshment. Structure and enrichment of vocabulary, two things that are very different from the nature of reading. Third, often reading activities are accompanied by translation into Indonesian, which obviously can develop unfavorable habits. Reading and translating are two kinds of discussion activities that are very different, although between there is a relationship.

Reading is a form of interaction with language, and therefore reading is a language activity (Yuliana, 2013, Hariyati and Syakur, 2018). The reader is confronted with words, phrases and sentences and the visual media that complete them, which form a whole text with the grammar adopted. As an act of receptive language, reading can be matched by listening. However, reading has at least one main characteristic that distinguishes it from listening (Budiarta and Krismayani, 2014). This characteristic is that reading is solitary, not social, in the sense that the dependency of 
the listener on the speaker does not exist with the reader on the script writer (Páez and Rinaldi, 2006). Thus, the reader is more free to interpret and can adjust the speed and repeat parts that are difficult to understand. The best way to teach reading is to give students text or reading texts to read. Because reading is very important. Similar to the ability to read English texts, if there is no encouragement from lecturers, students majoring in animal husbandry at the University of Nahdlatul Ulama Blitar feel that reading English textbooks is a difficult thing to do or say, then lecturer interference in this case is also needed especially those who are with regard to new vocabulary. The results obtained from reading must be comprehension, namely the ability of the reader to understand the contents of the manuscript or implied information conveyed in the manuscript he reads. So basically there are two types of reading, namely reading for understanding and reading for pleasure, although both produce understanding as a result of these activities.

According to how much the reader wants to obtain, there are four reading techniques, namely skimming, scanning, intensive reading and extensive reading (Mukundan, 2014, Ngoc, 2015). Skimming is a way to read quickly to find the essence of reading. Scanning is to read quickly to find certain information from the target text. Extensive reading is directed at long texts, and usually for fun, is an activity that requires fluency, and includes understanding globally. On the other hand, intensive reading is directed at short texts, to capture specific information, more activities that require accuracy and include a detailed understanding. Even though the target of reading is written language, reading ability is related to verbal ability. Knowledge of language and the area that becomes the capital of the reader includes words and expressions that have been heard or spoken before. The ability to understand reading is then closely related to the ability to listen or understand the script reading.

Based on the main problems outlined above, the main problem that will be examined in this study is "What kind of reading learning model can improve reading comprehension skills in students learning English to students in animal husbandry department at the University of Nahdlatul Ulama Blitar.

\section{Review of Literature}

\subsection{Definition of Reading}

According to Hariyati and syakur (2018) "Reading is a process that is carried out and used by readers to obtain messages, which will be conveyed by the writer through the media of words / written language. A process that demands that groups of words which are a unity be seen in a glance, so that the meaning of individual words will be known. If this is not fulfilled then the written and implied messages will not be captured or understood and the reading process will not be carried out properly. Reading is a way to get information from something written. Reading involves the introduction of symbols that make up a language. From the several definitions of reading that have been described above, it can be concluded that reading is an activity that involves vision, memory, intelligence, and understanding to obtain information conveyed by the writer through symbols.

\subsection{Reading Process}

The process of reading is a complex process. This process involves a number of physical and mental activities. The reading process consists of nine aspects, namely sensory, perceptual, sequence, experience, thoughts, learning, associations, and ideas (Hariyati and Syakur, 2018). The reading process begins with a visual sensory obtained through the expression of graphic symbols 
through the sense of sight. Reading is not an activity that stands alone, but is the result of various processes that are incorporated into an active reader attitude.

\subsection{Reciprocal Teaching Reading Strategies}

Reciprocal teaching is an instructional strategy that directly teaches students to apply met cognitive thinking when students make meaning from a text (Hariyati and Syakur, 2018). Furthermore, Hariyati and Syakur (2018) stated that "reciprocal teaching is an instructional procedure in which small groups of students learn to improve their reading comprehension through scaffold instruction of comprehension-monitoring strategies".

The philosophical foundation of a reciprocal teaching reading strategy is a social constructivist that includes the social aspects of reading activities Slavin and Madden (2001). Two social constructivist assumptions about reading according (Lindsey et al., 2003) are: (1) that social context plays an important role in the reading process, and (2) readers who are knowledgeable in culture can help readers who lack knowledge in the learning process of reading they.

The psychological foundation applied is a theory that supports cognitive theory including the theories of Piaget, Vygostky, Bruner and Ausubel. While the principles underlying reciprocal teaching are cognitive apprenticeship (Ngoc, 2015) the zone of proximal development (ZPD) (Manis et al., 2004), and prolepsis teaching (Wats and Wats, 2009). Meanwhile, reciprocal teaching theory (Yuliana, 2013) presents three key features, namely: scaffolding and explicit instruction, four main strategies (predicting, generating questions, clarifying, and summarizing), and social interaction.

\subsection{Reading and Learning English}

Reading is an active receptive activity. Receptive, that is when reading, the reader gets the information or message that the writer wants to convey. Active when reading, the reader performs active activities using his visual and cognitive abilities to be able to interpret the symbols he sees and interpret them, so that the contents of the reading can be understood and meaningful.

Regarding English lessons in higher education primarily vocational education that English is studied more deeply than others for work purposes, then the English language is vocational education. This statement implies that the teaching of English at the University of Nahdlatul Ulama Blitar is deeper as a provision to enter the workforce.

\section{Research Methods}

The method used in this research is the research and development method. This R\&D activity takes place in the form of a cycle, starting from the initial search stage, product development, testing and improvement. The use of this method is considered appropriate because this method can be used to describe the results of the level of assessment student reading.

On the other hand, this research was conducted by researchers through observation, interviews, questionnaires, and tests. In limited trials, the data collection techniques used was observation, and questionnaires. In extensive trials the data collection techniques were carried out through observation and tests. While to find out the increase in students' reading comprehension skills, data processing was carried out quantitatively using SPSS IBM Type statistical programs 25. 


\section{Discussion}

\subsection{Preliminary Study Results (Pre-Survey)}

There are two kinds of data obtained, namely the conditions of learning to read comprehension at the University of Nahdlatul Ulama Blitar and the learning process profile. Learning conditions can be said to be generally quite adequate, this is known from the condition of lecturers and students including facilities, facilities and infrastructure that support the learning process of reading comprehension in learning English. Regarding the learning process profile, lecturers tend to use teacher-centered and in evaluating learning, lecturers use tests.

\subsection{Limited Test Results}

The design of learning models to improve students' reading comprehension skills in learning English using reciprocal teaching strategies and peer tutoring methods in this limited trial are: 1) scaffolding, (2) formation and division of tasks in groups, (3) reading exploration, (4) rescaffolding, (5) presentation of the results of group work, (6) checking understanding, (7) reflection and conclusions, and finally (8) formative evaluation.

The eight learning activities above make the learning model developed a learning model in which the understanding of knowledge is built by students actively and critically, the pressure of the learning process lies with the students, the learning pressure on the process and learning outcomes, teaching is helping students learn, and the emphasis of learning in a way study groups so students can give each other the skills and experience they had before or in the form of new meanings.

\subsection{Extensive Test Results}

To determine the validity and reliability of the test, researchers used Pearson ProductMoment Correlation and Split-half Method. From the Spearman Brown calculation results obtained a correlation of 0.665 for the control class and 0.644 for the experimental class. Thus, it can be said that the items on the test have reliability high. Extensive testing was carried out at the University of Nahdlatul Ulama Blitar based on good, moderate and less categories. Before the $t$ test, researchers applied the Normality Test (Kolmogorov-Smirnov Test) and Homogeneity Test (Levene Statistics).

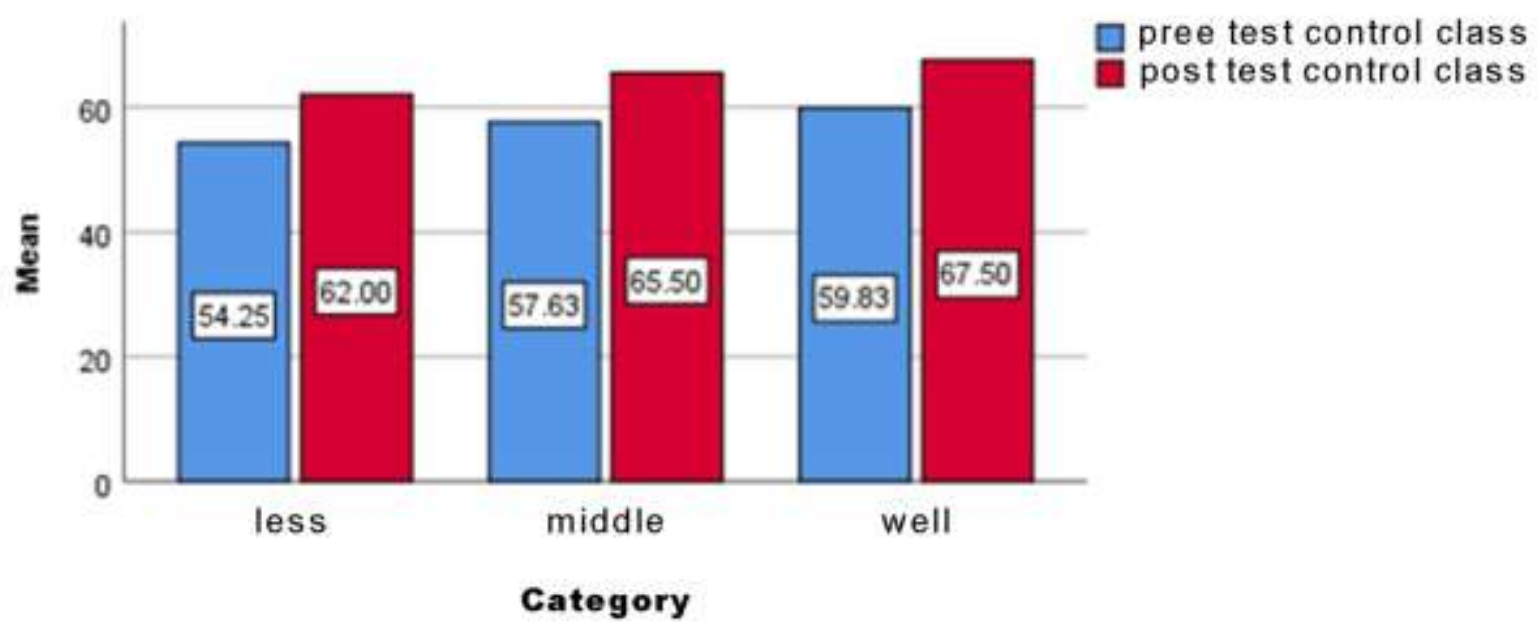

Figure 1. Pre-test and Post-test Results of Area Control Class Tests 


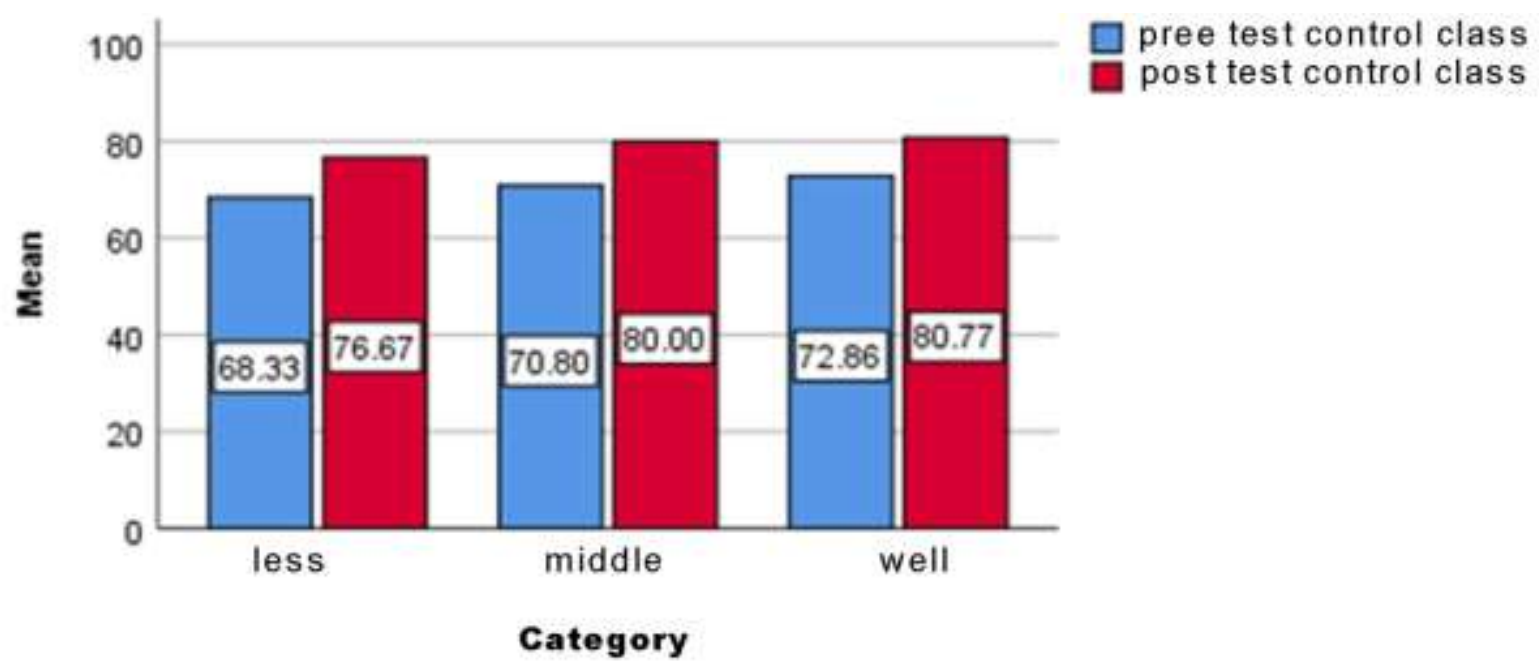

Figure 2. Results of Pre-test and Post-test Experiment Class Area Test

Based on the results of the $t$ test at the University of Nahdlatul Ulama Blitar in good category, the average value of control class students before getting treatment was 59.83 . But after being given learning to read by using the reciprocal learning method, the average value of students is 67.50. The average value of students who are in the medium category before getting treatment is 57.63. However, after treatment using reciprocal learning methods, the average student score reached 65.50 . While the average value of students who are at the University of Nahdlatul Ulama Blitar categorized less before getting treatment is 54.25. However, after treatment using the reciprocal learning method, the average student score reached 62 . These results indicate that there is an increase in the average value of students in the University of Nahdlatul Ulama Blitar on the ability to read understanding English for professions for the control class.

Based on the results of the $t$ test at the University of Nahdlatul Ulama Blitar in good category, the average value of control class students before receiving treatment was 72.86 . However, after learning to read using the peer-teaching method, the average student score was 80.77. The average value of students who are in the medium category before getting treatment is 70.80. However, after treatment using a peer-teaching method, the average value of students reached 80 . While the average value of students who were at the University of Nahdlatul Ulama Blitar was categorized as less before getting treatment was 68.33. However, after being treated using a peer-teaching method, the average student score reached 76.67. These results indicate that there is an increase in the average scores of students in the University of Nahdlatul Ulama Blitar in the ability to read English understanding for professions for experimental classes.

In the extensive test there was no improvement to the learning model. Improving the learning model only to the problems faced by the lecturer in each learning activity in the stages of implementing the learning model development. Improvement of the learning model was intended to further sharpen the learning model developed so as to improve students' reading comprehension skills. in learning English. 


\subsection{Validation Test Results}

The validation test took place at the University of Nahdlatul Ulama Blitar. The model validation test at the faculty level at the University of Nahdlatul Ulama Blitar was done with (good category) and (medium category), while the model validation test at the level of animal husbandry department of Nahdlatul Ulama University Blitar (less category). Both groups (experiment and control) in this design were given a pre-test and then treated using a learning model of reading comprehension that had been developed previously. While the control group used learning which has been used in learning to read comprehension in learning English. In this study used pretest-posttest control group design matching. Before the t test was carried out on both groups (experimental and control), the first prerequisite $t$ test was the normality test (Kolmogorov-Smirnov test) and the homogeneity test (Levene Statistics).

Table 1. Tests of Normality

Kolmogorov-Smirnov ${ }^{a}$

Shapiro-Wilk

\begin{tabular}{l|r|r|r|r|r|r} 
& \multicolumn{1}{c|}{ Statistic } & \multicolumn{1}{c|}{ df } & \multicolumn{1}{c|}{ Sig. } & Statistic & \multicolumn{1}{c|}{ df } & \multicolumn{1}{c}{ Sig. } \\
\hline pre-test control class & .108 & 30 & $.200^{*}$ & .961 & 30 & .327 \\
\hline $\begin{array}{l}\text { post-test control class } \\
\begin{array}{l}\text { pre-test experimental } \\
\text { class }\end{array}\end{array}$ & .139 & 30 & .142 & .905 & 30 & .011 \\
\hline $\begin{array}{l}\text { post-test experimental } \\
\text { class }\end{array}$ & .095 & 30 & .138 & .937 & 30 & .077 \\
\hline
\end{tabular}

*. This is a lower bound of the true significance.

a. Lilliefors Significance Correction

Table 2. Test of Homogeneity of Variances

\begin{tabular}{|c|c|c|c|c|c|}
\hline & & $\begin{array}{l}\text { Levene } \\
\text { Statistic }\end{array}$ & df1 & $\mathrm{df} 2$ & Sig. \\
\hline \multirow{4}{*}{$\begin{array}{l}\text { control } \\
\text { results }\end{array}$} & Based on Mean & .995 & 1 & 58 & .323 \\
\hline & Based on Median & .940 & 1 & 58 & .336 \\
\hline & $\begin{array}{l}\text { Based on Median and } \\
\text { with adjusted } \mathrm{df}\end{array}$ & .940 & 1 & 56.943 & .336 \\
\hline & Based on trimmed mean & .850 & 1 & 58 & .360 \\
\hline \multirow{4}{*}{$\begin{array}{l}\text { experimental } \\
\text { test results }\end{array}$} & Based on Mean & .217 & 1 & 58 & .643 \\
\hline & Based on Median & .189 & 1 & 58 & .666 \\
\hline & $\begin{array}{l}\text { Based on Median and } \\
\text { with adjusted df }\end{array}$ & .189 & 1 & 57.951 & .666 \\
\hline & Based on trimmed mean & .218 & 1 & 58 & .642 \\
\hline
\end{tabular}

Based on Table 1, it can be concluded that in the Kolmogorov Smirnov test all results have met the normality assumption due to the sig value. $>0.05$. Then it will proceed to the homogeneity test with the levene test in Table 2 where it can be concluded that both the control class and the experimental class have fulfilled the homogeneity assumption due to the sig value. amounted to 0.323 (control class) and 0.643 (experimental class) more than 0.05 . This means that all assumptions of both normality and homogeneity are met. Therefore, it can proceed to the paired t test. 
Table 3. Results of the average value of the control and experimental class

\begin{tabular}{llr|r|} 
& & Mean & \multicolumn{1}{c|}{ N } \\
\hline Pair 1 & pretest control class & 58.50 & 30 \\
\cline { 2 - 4 } & posttest control class & 66.23 & 30 \\
\hline Pair 2 & pre-test experimental class & 72.07 & 30 \\
\cline { 2 - 4 } & posttest experimental class & 80.23 & 30 \\
\hline
\end{tabular}

Table 4. Paired t test results

\begin{tabular}{ll|l|r|r} 
& & $\mathrm{t}$ & $\mathrm{df}$ & Sig. (2-tailed) \\
\hline Pair 1 & $\begin{array}{l}\text { pretest control class } \\
\text { posttest control class }\end{array}$ & -14.728 & 29 & .000 \\
\hline Pair 2 & $\begin{array}{l}\text { pretest experimental class } \\
\text { posttest experimental class }\end{array}$ & -20.643 & 29 & .000 \\
\hline
\end{tabular}

Based on Table 3, it can be concluded that on average the value of the control class is smaller than the experimental class. The average value of the pre-test control class was 58.50 while the experimental class was 72.07. The average value of the post test control class was 66.23 while in the experimental class it was 80.23 .

Based on the results in Table 4 it can be seen that the value of sig. $<0.05(0,000<0.05)$ so it can be concluded that there are differences in the results of the pre-test and post-test of the average value of students in English for professions.

\subsection{Effectiveness of Reciprocal Teaching Learning Model}

To see the effectiveness of the learning model developed in this study, a statistical test was performed by comparing the experimental group's gain scores with the control group's gain scores. T test results show that the gain score (pre-test and post-test) of the control group is smaller than the gain score (pre-test and post-test) of the experimental group.

Images 1 and 2 above show the gain score of the experimental group is higher than the gain score of the control group. In short, the reading comprehension learning model developed is more effective in improving the reading comprehension ability of the University of Nahdlatul Ulama Blitar students in learning English than the learning done so far by the lecturer.

From the results of the Assessment There are aspects of social value improvement such as: high levels of socialization among students, mutual respect for differences of opinion, mutual help, tolerance, and cooperation as a nurturing effect from the implementation of reciprocal teaching learning are in line with expectations. 


\section{Conclusion}

Based on the results of research and discussion it can be concluded that almost all students can feel it including: First, the condition of learning to read comprehension in English learning is more directed to the mastery of knowledge (cognitive) with teacher centered learning. Second, reciprocal teaching learning models that are seen to increase value social values among students are elaborated using peer tutoring methods. The design of the developed learning model consists of: are: 1) scaffolding, (2) formation and division of tasks in groups, (3) reading exploration, (4) re-scaffolding, (5) presentation of group work results, (6) understanding, (7) reflection and conclusions, and finally (8) formative evaluation. Third, with the aforementioned research that reading needs to be considered and implemented and developed with innovative learning the learner so that the interests and learning outcomes of reading for students are not centralized on instructors and lecturers but can become student centers.

\section{References}

Agussani, A. and K. Ansari. 2020. The Approach to Indonesian Language and Literature Curriculum in the Industrial Revolution Era 4.0 and Society 5.01. Kumpulan Penelitian dan Pengabdian Dosen.

Azis, R. and D. Kurniawan. 2019. Strategi Peningkatan Kemampuan Peternak Itik Melalui Pelatihan Manajemen Pakan Itik Terhadap Kelompok Peternak Itik Hibrida Super di Desa Slorok Kecamatan Doko Kabupaten Blitar. Jurnal Pengabdian dan Pemberdayaan Nusantara (JPPNu) 1(1):25-31.

Budiarta, I. K. and N. W. Krismayani. 2014. Improving speaking skill and developing character of the students through collaboration of think-pair-share and the concept of tri kaya parisudha. Jurnal Santiaji Pendidikan (JSP) 4(2):73-80.

Hariyati, N. R. and A. Syakur. 2018. Penerapan Strategi Membaca Kritis di Akademi Farmasi Surabaya untuk Menunjang Kecakapan Literasi Menuju Era Revolusi Industri 4.0. in Proc. Prosiding Seminar Nasional \& Internasional.

Hermann, M., T. Pentek, and B. Otto. 2016. Design principles for industrie 4.0 scenarios. Pages 3928-3937 in Proc. 2016 49th Hawaii international conference on system sciences (HICSS). IEEE.

Jöns, H. and M. Hoyler. 2013. Global geographies of higher education: The perspective of world university rankings. Geoforum 46:45-59.

Lindsey, K. A., F. R. Manis, and C. E. Bailey. 2003. Prediction of first-grade reading in Spanishspeaking English-language learners. Journal of educational psychology 95(3):482.

Ma, J., S. Baum, M. Pender, and D. W. Bell. 2015. Trends in College Pricing, 2015. Trends in Higher Education Series. College Board.

Manis, F. R., K. A. Lindsey, and C. E. Bailey. 2004. Development of reading in grades K-2 in Spanish-speaking English-language learners. Learning Disabilities Research \& Practice 19(4):214-224.

Mukundan, J. 2014. Chapter Six Readerthon: An Intensive And Extensive Reading Programme. Focusing on EFL Reading: Theory and Practice:129.

Ngoc, N. T. M. 2015. The essential roles of Skimming and Scanning Techniques in teaching reading comprehension. Retrieved on July 4:2017.

Ningsih, A., Y. Sabat, and A. Syakur. 2014. Comic Strips as Media to Develop Student's Writing Ability in Composing Recount Text for The Tenth Graders of SMA Muhammadiyah 2 Sidoarjo (Komik Strips Sebagai Media Untuk Mengembangakan Kemampuan Menulis Siswa Dalam Mengarang Teks Recount. English Education 2(2). 
Páez, M. and C. Rinaldi. 2006. Predicting English word reading skills for Spanish-speaking students in first grade. Topics in Language Disorders 26(4):338.

Robles, M. M. 2012. Executive perceptions of the top 10 soft skills needed in today's workplace. Business communication quarterly 75(4):453-465.

Sulam, K., A. Syakur, and L. Musyarofah. 2019. The Implementation of 21St Century Skills As The New Learning Paradigm to The Result Of Student's Career And Life Skills. Magister Scientiae 2(46):228-237.

Wats, M. and R. K. Wats. 2009. Developing Soft Skills in Students. International Journal of Learning 15(12).

Widiastuti, U., et al. (2019). Development of Traditional Harmony-Based Teaching Materials Based on HOTS to Improve Student Musicality of Music Education Program at Language and Art Faculty at State University of Medan (UNIMED). Budapest International Research in Linguistics and Education Sciences (BirLE) Journal, 2(4); 227238.

Yuliana, A. S., and A. Soegito. 2013. The application of audiolingual method to improve students speaking ability. Jurnal Pendidikan Bahasa Inggris STKIP PGRI Sidoarjo 1(1):88-93. 